\title{
IMPACT OF INCREASED ALUMINATE CONCENTRATIONS ON PROPERTIES OF SALTSTONE MIXES
}

\author{
J. R. Harbour, T. B. Edwards, E. K. Hansen and V. J. Williams \\ Savannah River National Laboratory
}

October 2007

Process Science and Engineering Savannah River National Laboratory Aiken, SC 29808

Prepared for the U.S. Department of Energy Under Contract Number DEAC09-96SR18500

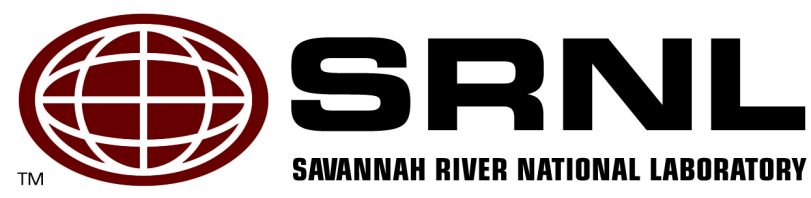




\section{DISCLAIMER}

This report was prepared by Washington Savannah River Company (WSRC) for the United States Department of Energy under Contract No. DE-AC09-96SR18500 and is an account of work performed under that contract. Neither the United States Department of Energy, nor WSRC, nor any of their employees makes any warranty, expressed or implied, or assumes any legal liability or responsibility for the accuracy, completeness, or usefulness, of any information, apparatus, or product or process disclosed herein or represents that its use will not infringe privately owned rights. Reference herein to any specific commercial product, process, or service by trademark, name, manufacturer or otherwise does not necessarily constitute or imply endorsement, recommendation, or favoring of same by WSRC or by the United States Government or any agency thereof. The views and opinions of the authors expressed herein do not necessarily state or reflect those of the United States Government or any agency thereof.

\section{Printed in the United States of America}

Prepared For

U.S. Department of Energy 
Key Words: Aluminum Dissolution Heat of Hydration Set time

Retention: Permanent

\section{IMPACT OF INCREASED ALUMINATE CONCENTRATIONS ON PROPERTIES OF SALTSTONE MIXES}

J. R. Harbour, T. B. Edwards, E. K. Hansen and V. J. Williams

Savannah River National Laboratory

October 2007

Process Science and Engineering

Savannah River National Laboratory

Aiken, SC 29808

Prepared for the U.S. Department of Energy Under Contract Number DEAC09-96SR18500

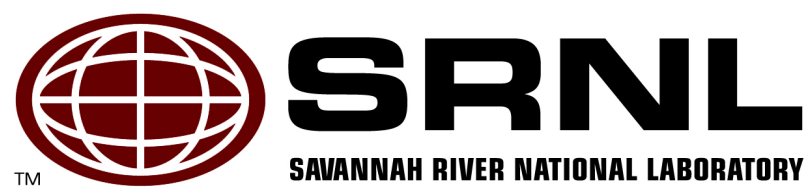




\section{REVIEWS AND APPROVALS}

\section{AUTHORS:}

J. R. Harbour, SRNL, Stabilization Science Research

Date

T. B. Edwards, SRNL, Computational and Statistical Science

Date

E. K. Hansen, SRNL, Stabilization Science Research

Date

V. J. Williams, SRNL, Stabilization Science Research

Date

\section{TECHNICAL REVIEWERS:}

A. D. Cozzi, SRNL, Stabilization Science Research

Date

\section{APPROVERS}

D. A. Crowley, SRNL, Manager, Stabilization Science Research

Date

R. E. Edwards, SRNL, Manager, Process Science and Engineering

Date

J. E. Occhipinti, Manger, Waste Solidification Engineering

Date 


\section{EXECUTIVE SUMMARY}

One of the goals of the Saltstone variability study is to identify the operational and compositional variables that control or influence the important processing and performance properties of Saltstone mixes. The protocols developed in this variability study are ideally suited as a tool to assess the impact of proposed changes to the processing flow sheet for Liquid Waste Operations (LWO). One such proposal that is currently under consideration is to introduce a leaching step in the treatment of the High Level Waste (HLW) sludge to remove aluminum prior to vitrification at the Defense Waste Processing Facility (DWPF). This leachate would significantly increase the soluble aluminate concentrations as well as the free hydroxide ion concentration in the salt feed that will be processed at the Saltstone Processing Facility (SPF). Consequently, an initial study of the impact of increased aluminate concentration on the Saltstone grout properties was performed. The projected compositions and ranges of the aluminate rich salt stream (which includes the blending strategy) are not yet available and consequently, in this initial report, two separate salt stream compositions were investigated. The first stream starts with the previously projected baseline composition of the salt solution that will be fed to SPF from the Salt Waste Processing Facility (SWPF). The second stream is the solution that results from washing of the current Tank 51 sludge and subsequent transfer of the salt solution to Tank 11. The SWPF simulant has higher nitrate and lower free hydroxide than the Tank 11 simulant. In both of these cases, the aluminate was varied up to a maximum of 0.40 to $0.45 \mathrm{M}$ aluminate in order to evaluate the impact of increasing aluminate ion concentration on the grout properties.

In general, the fresh grout properties of mixes made with SWPF and Tank 11 simulants were relatively insensitive to an increase in aluminate concentration in the salt solutions. However, the overall trends observed as the aluminate concentration increased in the salt solution were decreased Bingham Plastic yield stress and plastic viscosity, greater flowability of the grout, and reduced gel times and bleed volume for SWPF based mixes.

On the other hand, the set times increased significantly with increasing aluminate concentration in the salt solutions. For the SWPF mixes, the set time increased from 1 to 4 days and for the Tank 11 mixes, the set time increased from 1 to 2 days. Heat of hydration measurements were consistent with the increased set times with extended induction periods ( 2 to 4 days) as aluminate concentration increased in the salt solution. This extended induction period of heat evolution observed with increasing aluminate concentrations must be addressed for Saltstone operations to avoid exceeding temperature limits. It is anticipated that the induction period will be temperature dependent and should be measured for future projections and included in the thermal modeling.

The overall heat generation was greater in the mixes containing higher concentrations of aluminate. In fact, for the total heat release values calculated using curve fitting for longer times, the amount of heat was increased by $33 \%$ for SWPF based solutions and by $46 \%$ for Tank 11 based solutions. The larger amount of heat from mixes containing higher aluminate concentration must be accounted for in the modeling effort which determines the pour schedule for Saltstone.

The increased induction periods were shown to be associated with hydration reactions of the blast furnace slag. The rate of heat generation with high aluminate solutions and Portland 
cement were only accelerated whereas high aluminate mixes containing blast furnace slag only showed the characteristic increase in induction time that was observed with mixes prepared using the premix blend of cementitious materials. It was shown that fly ash does not react significantly during the first seven days of curing but then undergoes an accelerated burst for 15 days before beginning to level off. The total amount of heat generated from a fly ash only mix with SWPF solution containing aluminate at $0.33 \mathrm{M}$ is approximately $100 \mathrm{~J} / \mathrm{g}$ vs. $87 \mathrm{~J} / \mathrm{g}$ for SWPF with 0.11 $\mathrm{M}$ aluminate. Finally, the heat of hydration measurements revealed that the ternary system of cementitious materials (premix) leads to interactions between the hydration reactions of these three components that actually reduce the overall heat generation compared to the summation of the heats of hydration for mixes made only from portland cement, blast furnace slag or fly ash. 
TABLE OF CONTENTS

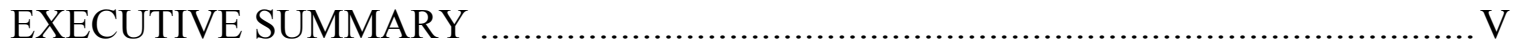

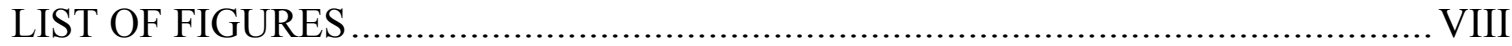

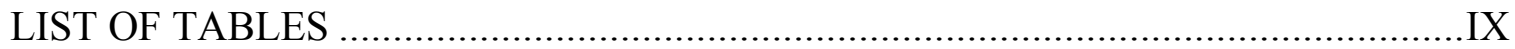

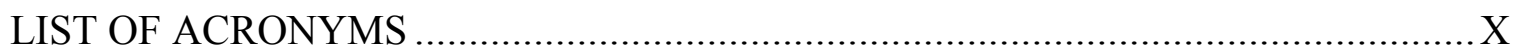

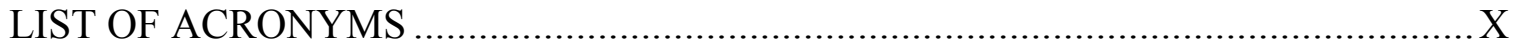

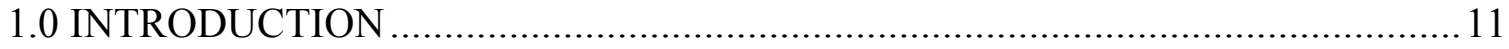

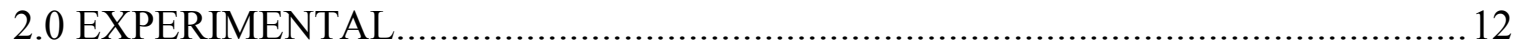

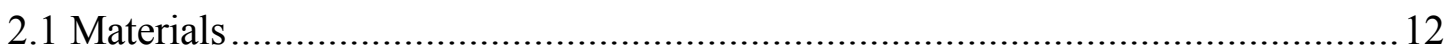

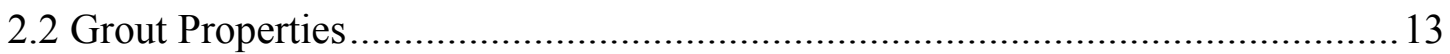

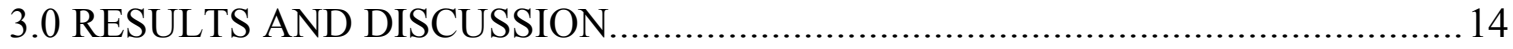

3.1 Fresh and Cured Properties of Mixes Prepared with SWPF Simulants.................14

3.2 Fresh and Cured Properties of Mixes Prepared with Tank 11 Simulants ..............18

3.3 The Role of the Cementitious Material on the Aluminum Effect ........................21

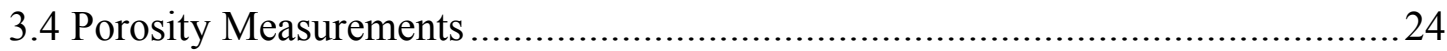

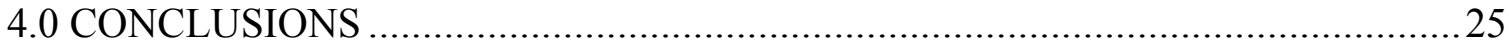

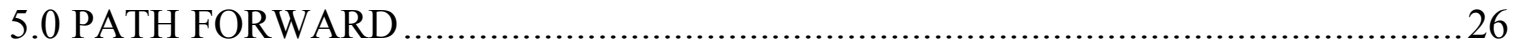

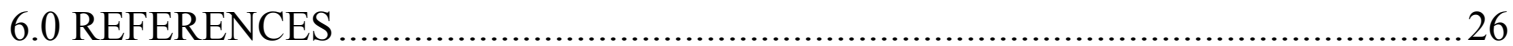




\section{LIST OF FIGURES}

Figure 3-1 Superposition of the flow curves for GVS74 through GVS77 …………................. 15

Figure 3-2 Normalized heat flow and normalized heat for GVS74 ….................................... 16

Figure 3-3 Normalized heat flow and normalized heat for GVS76 ...................................... 17

Figure 3-4 Superposition of the flow curves for GVS78 through GVS80 ............................... 19

Figure 3-5 Normalized heat flow and normalized heat for GVS80 …..................................... 20

Figure 3-6 Heat of hydration response (J/g of FA) for a mix made from FA and SWPF simulant

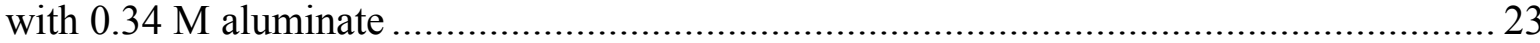




\section{LIST OF TABLES}

Table 2-1 Saltstone Cementitious Materials

Table 2-2 Composition of the Four SWPF Mixes with Varying Aluminate Concentration ....... 12

Table 2-3 Composition of the Tank 11 Mixes with Varying Aluminate Concentration............ 13

Table 3-1 Fresh Grout Properties of SWPF Mixes as a Function of Aluminate Concentration

$(0.11$ to $0.45 \mathrm{M})$

Table 3-2 Set Time, 7-Day Heat of Hydration and Peak Times for Heat Flow for the SWPF

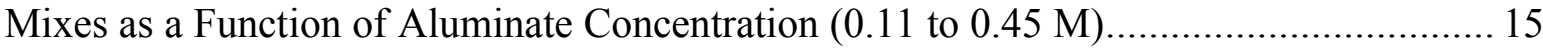

Table 3-3 Extended Heat of Hydration (by Curve Fitting) for GVS74 - GVS77 Mixes........... 17

Table 3-4 Compressive Strengths as a Function of Aluminate Concentration......................... 18

Table 3-5 Fresh Grout Properties of Tank 11 Mixes as a Function of Aluminate Concentration $(0.05$ to $0.40 \mathrm{M})$

Table 3-6 Set Time, 7-Day and Extended Heat of Hydration (Curve Fitting), and Peak Times for Heat Flow for the Tank 11 Mixes as a Function of Aluminate Concentration (0.05 to 0.40 M)

Table 3-7 Compressive Strengths as a Function of Aluminate Concentration for the Tank 11

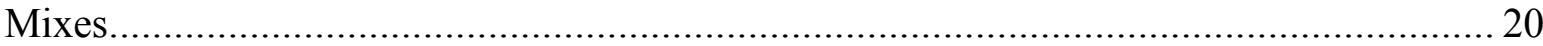

Table 3-8 Fresh Grout Properties of SWPF Mixes as a Function of Aluminate Concentration $(0.11$ or $0.34 \mathrm{M})$ with either OPC, GGBFS or FA as Cementitious Material................... 21

Table 3-9 Set Time, 7-Day Heat of Hydration and Peak Times for Heat Flow for the SWPF Mixes as a Function of Aluminate Concentration $(0.11$ or $0.34 \mathrm{M})$ with OPC, GGBFS or FA

Table 3-10 Time Dependence of the Heat of Hydration for the SWPF Mixes as a Function of Aluminate Concentration ( 0.11 or $0.34 \mathrm{M}$ ) with OPC, GGBFS or FA (NM is not measured)

Table 3-11 Heats of Hydration Values for GVS74 and GVS76 Mixes and Calculated (Summation) Values from Individual Contributions from Table 3-10. 24

Table 3-12 Porosity Measurements for Samples at Various Curing Times 


\section{LIST OF ACRONYMS}

\begin{tabular}{|l|l|}
\hline ACTL & Aiken County Technology Laboratory \\
\hline DWPF & Defense Waste Processing Facility \\
\hline FA & Fly Ash \\
\hline GGBFS & Ground Granulated Blast Furnace Slag \\
\hline GVS & Grout Variability Study \\
\hline HLW & High Level Waste \\
\hline LWO & Liquid Waste Operations \\
\hline NM & Not Measured \\
\hline OPC & Ordinary Portland Cement \\
\hline SDF & Saltstone Disposal Facility \\
\hline SPF & Saltstone Processing Facility \\
\hline SRNL & Savannah River National Laboratory \\
\hline SRS & Savannah River Site \\
\hline SWPF & Salt Waste Processing Facility \\
\hline TR & Trial Run \\
\hline w/cm & Water to Cementitious Material Ratio \\
\hline w/pm & Water to Premix Ratio \\
\hline
\end{tabular}




\subsection{INTRODUCTION}

One of the goals of the Saltstone variability study is to identify the operational and compositional variables that control or influence the important processing and performance properties of Saltstone grout mixtures [1]. The protocols developed in this variability study are ideally suited as a tool to assess the impact of proposed changes to the processing flow sheet for Liquid Waste Operations (LWO) [2]. One such proposal that is currently under consideration is to introduce a leaching step in the treatment of the High Level Waste (HLW) sludge to remove aluminum prior to vitrification at the Defense Waste Processing Facility (DWPF) [3]. This leachate would significantly increase the soluble aluminate concentrations as well as the free hydroxide ion concentration in the salt feed that will be processed at the Saltstone Processing Facility (SPF). Consequently, an initial study of the impact of increased aluminate concentration on the Saltstone grout properties was performed. The projected compositions and ranges of the aluminate rich salt stream (which includes the blending strategy) are not yet available and consequently, in this initial report, two separate salt stream compositions were investigated. The first stream starts with the previously projected baseline composition of the salt solution that will be fed to SPF from the Salt Waste Processing Facility (SWPF simulant) [4]. The second stream is the solution that results from washing of the current Tank 51 sludge and subsequent transfer of the salt solution to Tank 11 [3]. The SWPF simulant has higher nitrate and lower free hydroxide than the Tank 11 simulant. In both of these cases, the aluminate was varied up to a maximum of 0.40 to $0.45 \mathrm{M}$ aluminate in order to evaluate the impact of increasing aluminate ion concentration on the grout properties. 


\subsection{EXPERIMENTAL}

\subsection{Materials}

The cementitious materials were obtained from Saltstone in 5 gallon containers and are listed in Table 2-1. These materials were specified in a WSRC contract for Saltstone cementitious materials and arrived with the delivery of the cementitious materials to Saltstone. The materials were transferred to 2 liter plastic bottles at Aiken County Technical Laboratory (ACTL) and tightly sealed. Maintaining these materials in a tightly sealed container limits the exposure of the materials to humid air. Table 2-1 also contains the wt $\%$ contribution of each material used to make the premix.

Table 2-1 Saltstone Cementitious Materials

\begin{tabular}{|c|c|c|c|}
\hline Material & Category & Vendor & Premix Blend (wt\%) \\
\hline Portland cement (OPC) & Type II & Holcim & 10 \\
\hline Blast Furnace slag (GGBFS) & Grade I or II & Holcim & 45 \\
\hline Fly ash (FA) & Class F & SEFA & 45 \\
\hline
\end{tabular}

The SWPF simulant compositions are summarized in terms of the key components listed in Table 2-2. GVS74 is the baseline mix. The three other mixes (GVS75-GVS77) were altered by addition of aluminate up to $0.45 \mathrm{M}$ in GVS77. In order to ensure solubility of the aluminum as aluminate, $\mathrm{Al}(\mathrm{OH})_{4}^{-}$in the simulant it is necessary to add four hydroxide ions for every added aluminum ion. Therefore, for the maximum case of $0.45 \mathrm{M}$ aluminum, an excess of 4 times 0.45 or $1.80 \mathrm{M} \mathrm{OH}^{-}$was added to the simulant. This maintains the same free hydroxide level in all four cases. However, the overall sodium ion concentration as well as the sodium nitrate increases in GVS75 through GVS77 due to the addition of sodium hydroxide and aluminum nitrate. The rest of components remained the same and the processing parameters were also kept constant for these four mixes. The mixing was performed as previously described using a paddle blade mixer with a three minute mixing duration [2].

Table 2-2 Composition of the Four SWPF Mixes with Varying Aluminate Concentration

\begin{tabular}{|c|c|c|c|c|}
\hline Identifier & Aluminate (M) & Free $\mathbf{O H}^{-}(\mathbf{M})$ & w/premix & Nitrate (M) \\
\hline GVS74 & 0.11 & 2.4 & 0.60 & 2.31 \\
\hline GVS75 & 0.23 & 2.4 & 0.60 & 2.66 \\
\hline GVS76 & 0.34 & 2.4 & 0.60 & 2.99 \\
\hline GVS77 & 0.45 & 2.4 & 0.60 & 3.32 \\
\hline
\end{tabular}

The Tank 11 simulant compositions are summarized in terms of the key components in Table 2-3. GVS78 is the mix with low aluminate. The two other mixes (GVS79 and GVS80) were altered by addition of aluminate up to $0.40 \mathrm{M}$ in GVS80. In order to ensure solubility of the aluminum as aluminate, $\mathrm{Al}(\mathrm{OH})_{4}^{-}$in the simulant, it was again necessary to add additional sodium hydroxide. 
Table 2-3 Composition of the Tank 11 Mixes with Varying Aluminate Concentration

\begin{tabular}{|c|c|c|c|c|}
\hline Identifier & Aluminate (M) & Free $\mathbf{O H}^{-}(\mathbf{M})$ & w/premix & Nitrate (M) \\
\hline GVS78 & 0.05 & 3.6 & 0.60 & 0.35 \\
\hline GVS79 & 0.20 & 3.6 & 0.60 & 0.80 \\
\hline GVS80 & 0.40 & 3.6 & 0.60 & 1.40 \\
\hline
\end{tabular}

Mixes were also made using the batch sheets GVS74 and GVS76 but with $100 \%$ OPC, GGBFS or FA in place of the premix to determine the impact of the individual cementitious materials on the grout properties at both low $(0.11 \mathrm{M})$ and high $(0.40$ to $0.45 \mathrm{M})$ aluminate concentrations. The six mixes made with the individual cementitious components are referred to in this report as TR322 through TR327.

\subsection{Grout Properties}

The methods used for the measurements of both fresh and cured grout properties have been discussed previously and were used for this report [2, 4, and 5]. 


\subsection{RESULTS AND DISCUSSION}

The fresh and cured grout properties of mixes prepared using the SWPF and Tank 11 simulants were measured as a function of aluminate concentration. The details of the compositions of the simulants and mixes are presented in Section 2.0 of this report.

\subsection{Fresh and Cured Properties of Mixes Prepared with SWPF Simulants}

The fresh grout properties (and the cured grout density for comparison to the fresh grout density) for the SWPF simulants are presented in Table 3-1.

Table 3-1 Fresh Grout Properties of SWPF Mixes as a Function of Aluminate Concentration (0.11 to $0.45 \mathrm{M})$

\begin{tabular}{|c|c|c|c|c|c|c|c|c|}
\hline \multirow[b]{2}{*}{ Identifier } & \multirow[b]{2}{*}{$\begin{array}{l}\text { Gel Time } \\
\text { (minutes) }\end{array}$} & \multicolumn{2}{|c|}{ Bleed (vol\%) } & \multicolumn{2}{|c|}{ Density (g/mL) } & \multirow[b]{2}{*}{$\begin{array}{c}\text { Flow } \\
\text { (inches) }\end{array}$} & \multicolumn{2}{|c|}{ Bingham Plastic } \\
\hline & & 1 day & 3 Day & Fresh & Cured & & $\begin{array}{c}\text { Yield } \\
\text { Stress } \\
(\mathrm{Pa})\end{array}$ & $\begin{array}{c}\text { Plastic } \\
\text { Viscosity } \\
\text { (cP) }\end{array}$ \\
\hline GVS74 & 115 & 2.5 & 1.9 & 1.743 & 1.796 & 9.8 & 2.7 & 69.7 \\
\hline GVS75 & 52 & 1.2 & 1.0 & 1.751 & 1.801 & 10.0 & 2.0 & 66.5 \\
\hline GVS76 & 40 & 1.2 & 1.2 & 1.756 & 1.803 & 10.1 & 1.6 & 61.5 \\
\hline GVS77 & 50 & 0.6 & 1.0 & 1.767 & 1.806 & 9.9 & 1.4 & 67.2 \\
\hline
\end{tabular}

As the aluminate concentration increased from $0.11 \mathrm{M}$ (GVS74) through $0.45 \mathrm{M}$ (GVS77), the gel time, bleed volume and yield stress decreased. The fresh and cured grout densities both increased slightly, as expected due to the increased salt concentrations (and densities) in the simulants as aluminate concentration increased. The plastic viscosity and flow were essentially unchanged as a function of aluminate ion concentration. Figure 3-1 contains all the flow curves, which show little difference in the flow properties. These data demonstrate that increased aluminate in the nominal SWPF simulant had relatively little impact on the fresh grout properties. 


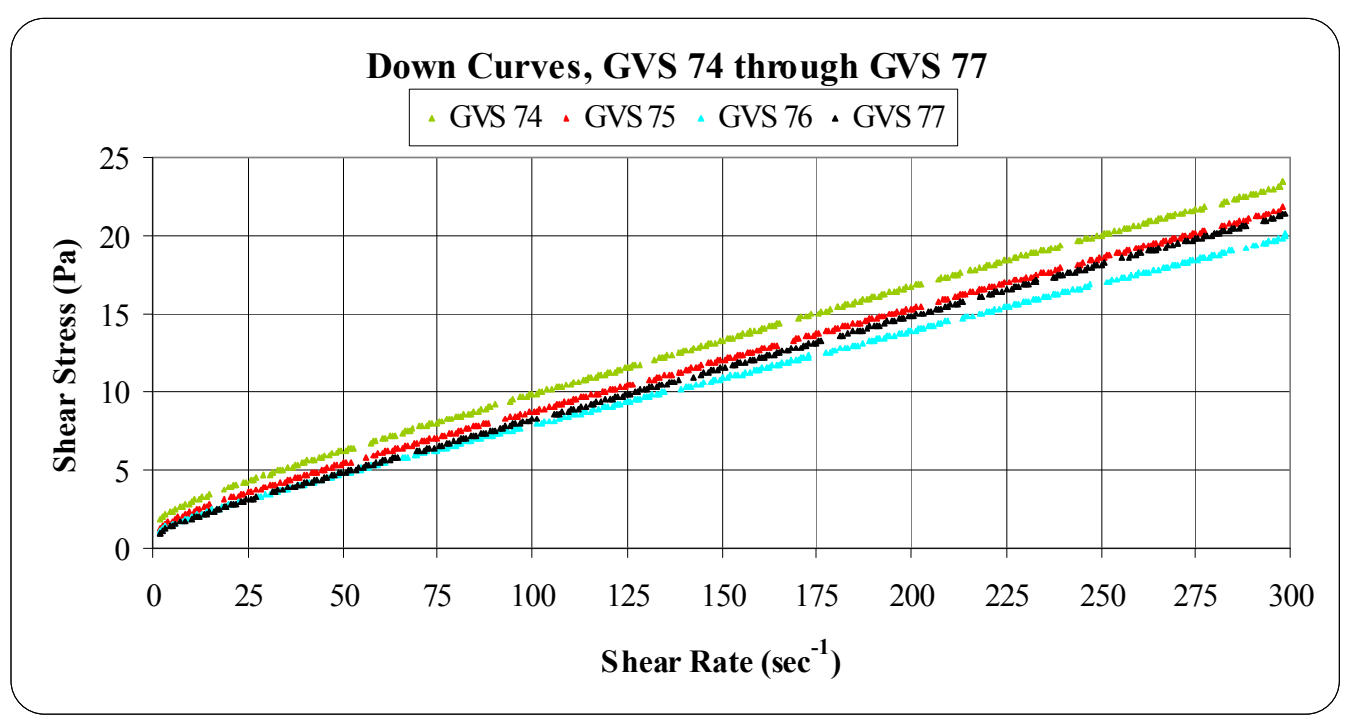

Figure 3-1 Superposition of the flow curves for GVS74 through GVS77

The set time and the 7-day heat of hydration data for these mixes are presented in Table 3-2. The data in this table reveal that an increase in the aluminate concentration increased the 7-day heat of hydration of the grout mix and significantly increased the induction period, quantified as the peak time for heat flow (the amount of time, starting with mixing, until heat generation from the hydration reactions is a maximum). The response is non-linear with the initial increase of aluminate from $0.11 \mathrm{M}$ to $0.22 \mathrm{M}(\mathrm{GVS} 75)$ resulting in a significant increase in both the heat of hydration and peak time.

Table 3-2 Set Time, 7-Day Heat of Hydration and Peak Times for Heat Flow for the SWPF Mixes as a Function of Aluminate Concentration (0.11 to $0.45 \mathrm{M})$

\begin{tabular}{|c|c|c|c|c|c|}
\hline \multirow{2}{*}{ Identifier } & \multirow{2}{*}{$\begin{array}{c}\text { Set } \\
\text { Time } \\
\text { (Days) }\end{array}$} & \multicolumn{2}{|c|}{$\begin{array}{c}\text { 7-Day Heat of } \\
\text { Hydration (J/g) }\end{array}$} & \multicolumn{2}{|c|}{ Peak Time } \\
\cline { 3 - 6 } & 1 & premix & grout & Minutes & Hours \\
\hline GVS74 & 141 & 76 & 334 & 6 \\
\hline GVS75 & 3 & 163 & 87 & 2820 & 47 \\
\hline GVS76 & 4 & 162 & 85 & 3399 & 57 \\
\hline GVS77 & 4 & 158 & 81 & 3448 & 57 \\
\hline
\end{tabular}

The peak time for heat flow correlates well with the set times measured for these grouts. That is, the set time increased as the peak time for heat flow increased. This is explained by the fact that a threshold for the degree of hydration (the fraction of cementitious material that reacts or hydrates) must be exceeded prior to a proper set of the grout. The heat of hydration data for the SWPF baseline (GVS74) is provided in Figure 3-2. The corresponding data for GVS76 with a higher aluminate concentration is provided in Figure 3-3. The figures reveal that the peak time increased from 6 to 57 hours as the aluminate concentration increased from 0.11 to $0.34 \mathrm{M}$. The set time increased from 1 to 4 days for these two mixes (GVS74 and GVS76). Further increase in aluminate concentration (up to $0.45 \mathrm{M}$ ) did not seem to impact these properties. 
WSRC-STI-2007-00506

Rev. 0

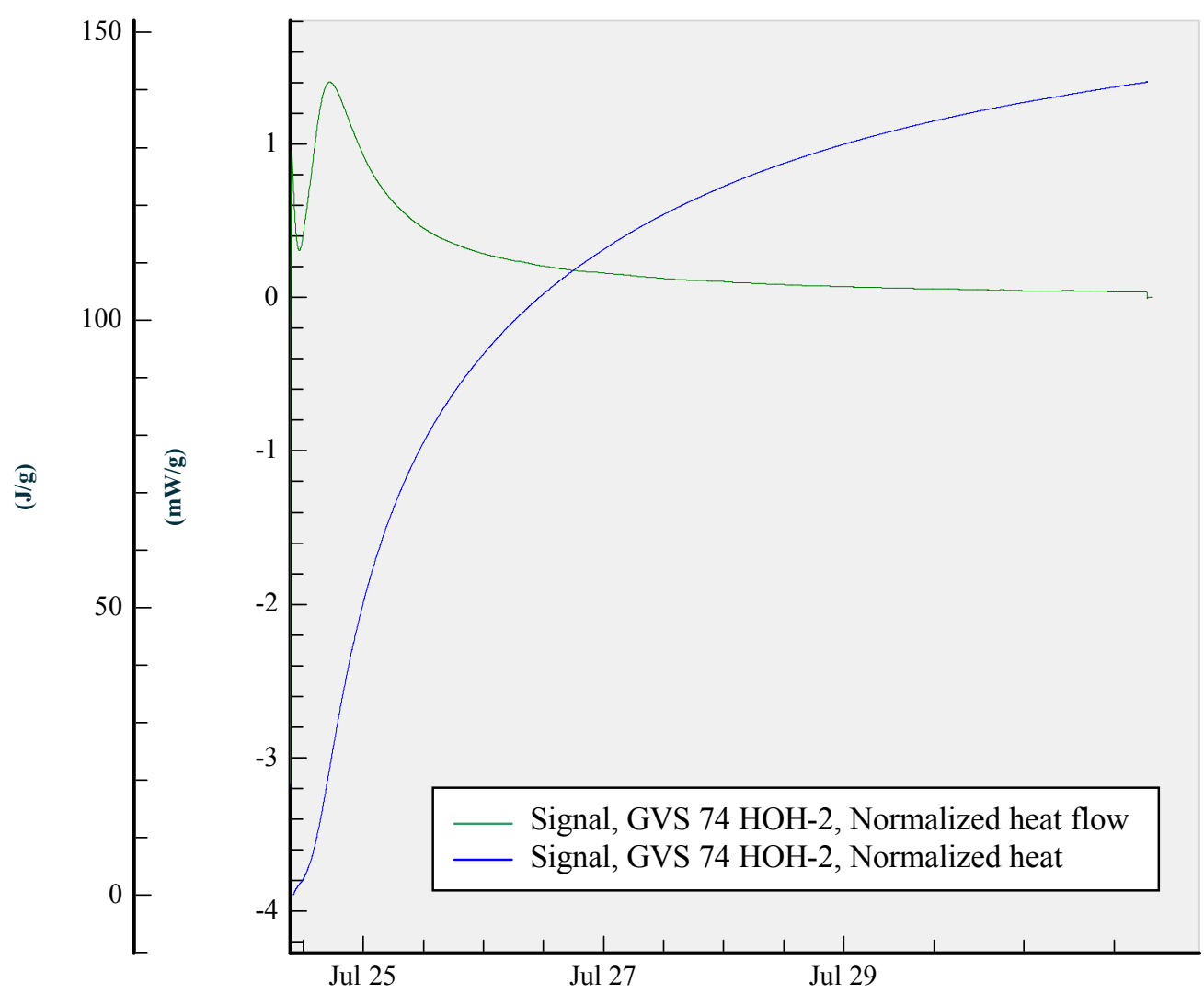

Figure 3-2 Normalized heat flow and normalized heat for GVS74 


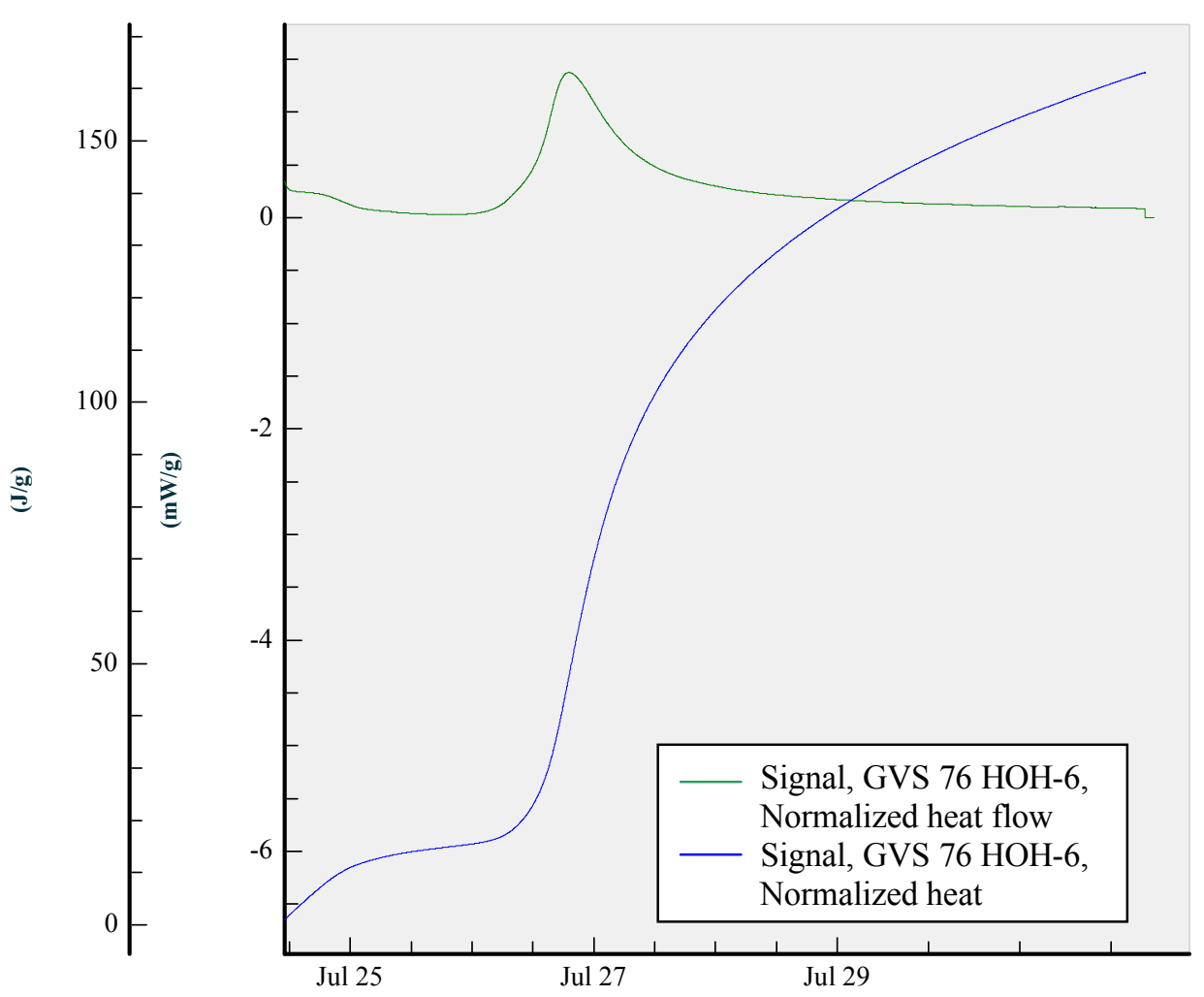

Figure 3-3 Normalized heat flow and normalized heat for GVS76

It is also evident from looking at Figure 3-2 and Figure 3-3 that the overall heat release from the GVS76 mix is increasing at a faster rate after seven days than the heat release from GVS74. This is due in part to the delayed onset of heat evolution in GVS76 and also in part due to the increased heat generation from increased aluminate concentration. The TAM Air isothermal calorimeter has a software package that can be used to estimate the total heat release at longer times by curve fitting the normalized heat curve with an exponential function [5]. These extended values for the total heat release (obtained by curve fitting) for the four mixes are provided in Table 3-3.

Table 3-3 Extended Heat of Hydration (by Curve Fitting) for GVS74 - GVS77 Mixes

\begin{tabular}{|c|c|c|c|}
\hline \multirow{2}{*}{ Identifier } & Set Time & \multicolumn{2}{|c|}{ Extended Heat of Hydration (J/g) } \\
\cline { 3 - 4 } & (Days) & premix & grout \\
\hline GVS74 & 1 & 150 & 81 \\
\hline GVS75 & 3 & 185 & 99 \\
\hline GVS76 & 4 & 200 & 105 \\
\hline GVS77 & 4 & 200 & 103 \\
\hline
\end{tabular}


The 28-day compressive strengths for the four mixes are given in Table 3-4. Although this data has uncertainty due to the abbreviated method for measurement, it is clear that increasing the aluminate concentration increases the value of the compressive strength,

Table 3-4 Compressive Strengths as a Function of Aluminate Concentration

\begin{tabular}{|c|c|c|}
\hline Identifier & $\begin{array}{c}\text { Cure Time } \\
\text { (Days) }\end{array}$ & $\begin{array}{c}\text { Compressive Strength } \\
\text { (psi) }\end{array}$ \\
\hline GVS74 & 28 & 1046 \\
\hline GVS75 & 28 & 1822 \\
\hline GVS76 & 28 & 1529 \\
\hline GVS77 & 28 & 1220 \\
\hline
\end{tabular}

\subsection{Fresh and Cured Properties of Mixes Prepared with Tank 11 Simulants}

The fresh grout properties (and the cured grout density for comparison to the fresh grout density) for the Tank 11 simulants are presented in Table 3-5.

Table 3-5 Fresh Grout Properties of Tank 11 Mixes as a Function of Aluminate Concentration $(0.05$ to $0.40 \mathrm{M})$

\begin{tabular}{|c|c|c|c|c|c|c|c|c|}
\hline \multirow[b]{2}{*}{ Identifier } & \multirow[b]{2}{*}{$\begin{array}{l}\text { Gel Time } \\
\text { (minutes) }\end{array}$} & \multicolumn{2}{|c|}{ Bleed (vol\%) } & \multicolumn{2}{|c|}{ Density (g/mL) } & \multirow[b]{2}{*}{$\begin{array}{c}\text { Flow } \\
\text { (inches) }\end{array}$} & \multicolumn{2}{|c|}{ Bingham Plastic } \\
\hline & & 1 day & 3 Day & Fresh & Cured & & $\begin{array}{c}\text { Yield } \\
\text { Stress } \\
(\mathrm{Pa})\end{array}$ & $\begin{array}{c}\text { Plastic } \\
\text { Viscosity } \\
\text { (cP) }\end{array}$ \\
\hline GVS78 & 30 & 0.0 & 0.0 & 1.75 & 1.764 & 9.1 & 3.8 & 85.8 \\
\hline GVS79 & 40 & 0.8 & 0.2 & 1.74 & 1.784 & 9.4 & 3.1 & 82.4 \\
\hline GVS80 & 30 & 0.4 & 0.0 & 1.75 & 1.787 & 9.6 & 2.3 & 78.9 \\
\hline
\end{tabular}

As the aluminate concentration increases from $0.05 \mathrm{M}$ (GVS78) through $0.40 \mathrm{M}$ (GVS80), the plastic viscosity and yield stress decrease and the flow increases. Figure 3-4 clearly shows that the flow curves for GVS78 through GVS80 are different. The cured grout density increased slightly as expected due to the increased salt (density) concentrations in the simulants as the aluminate concentration was increased. The gel time and the volume \% bleed are roughly unchanged. These data demonstrate that increased aluminate in the nominal Tank 11 simulant improved some of the properties slightly while not effecting the other properties. 


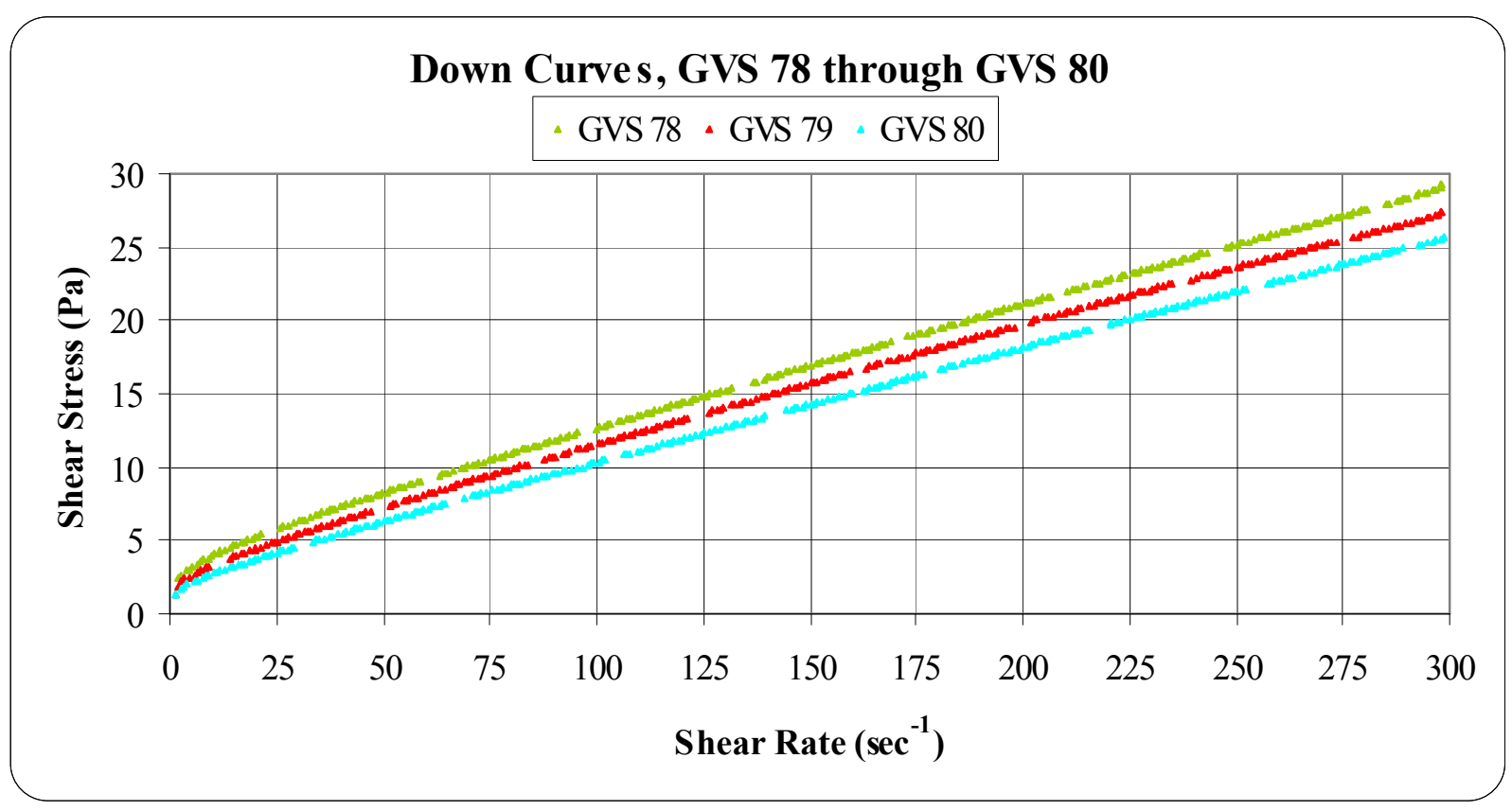

Figure 3-4 Superposition of the flow curves for GVS78 through GVS80

The set time, 7-day, and extended heat of hydration data for these mixes are presented in Table 3-6. An increase in the total heat evolution and induction period (peak time) with increasing aluminate concentration was observed with the Tank 11 simulant mixes. This is the same trend that was observed with the SWPF simulant mixes. The peak time for heat flow correlates well with the set times measured for these grouts, again consistent with the findings using the SWPF simulant mixes. Figure 3-5 provides the time dependence of the heat flow and heat of hydration for GVS80.

Table 3-6 Set Time, 7-Day and Extended Heat of Hydration (Curve Fitting), and Peak Times for Heat Flow for the Tank 11 Mixes as a Function of Aluminate Concentration (0.05 to $0.40 \mathrm{M})$

\begin{tabular}{|c|c|c|c|c|c|c|c|}
\hline \multirow{2}{*}{ Identifier } & \multirow{2}{*}{$\begin{array}{c}\text { Set } \\
\text { Time } \\
\text { (Days) }\end{array}$} & \multicolumn{2}{|c|}{$\begin{array}{c}\text { 7-Day Heat of } \\
\text { Hydration (J/g) }\end{array}$} & \multicolumn{2}{|c|}{ Peak Time } & \multicolumn{2}{c|}{$\begin{array}{c}\text { Extended Heat of } \\
\text { Hydration (J/g) }\end{array}$} \\
\cline { 3 - 8 } & premix & grout & Minutes & Hours & premix & grout \\
\hline GVS78 & 1 & 128 & 74 & 60 & 1 & 137 & 79 \\
\hline GVS79 & 1 & 156 & 88 & 566 & 9 & 167 & 95 \\
\hline GVS80 & 2 & 180 & 99 & 2239 & 37 & 200 & 110 \\
\hline
\end{tabular}




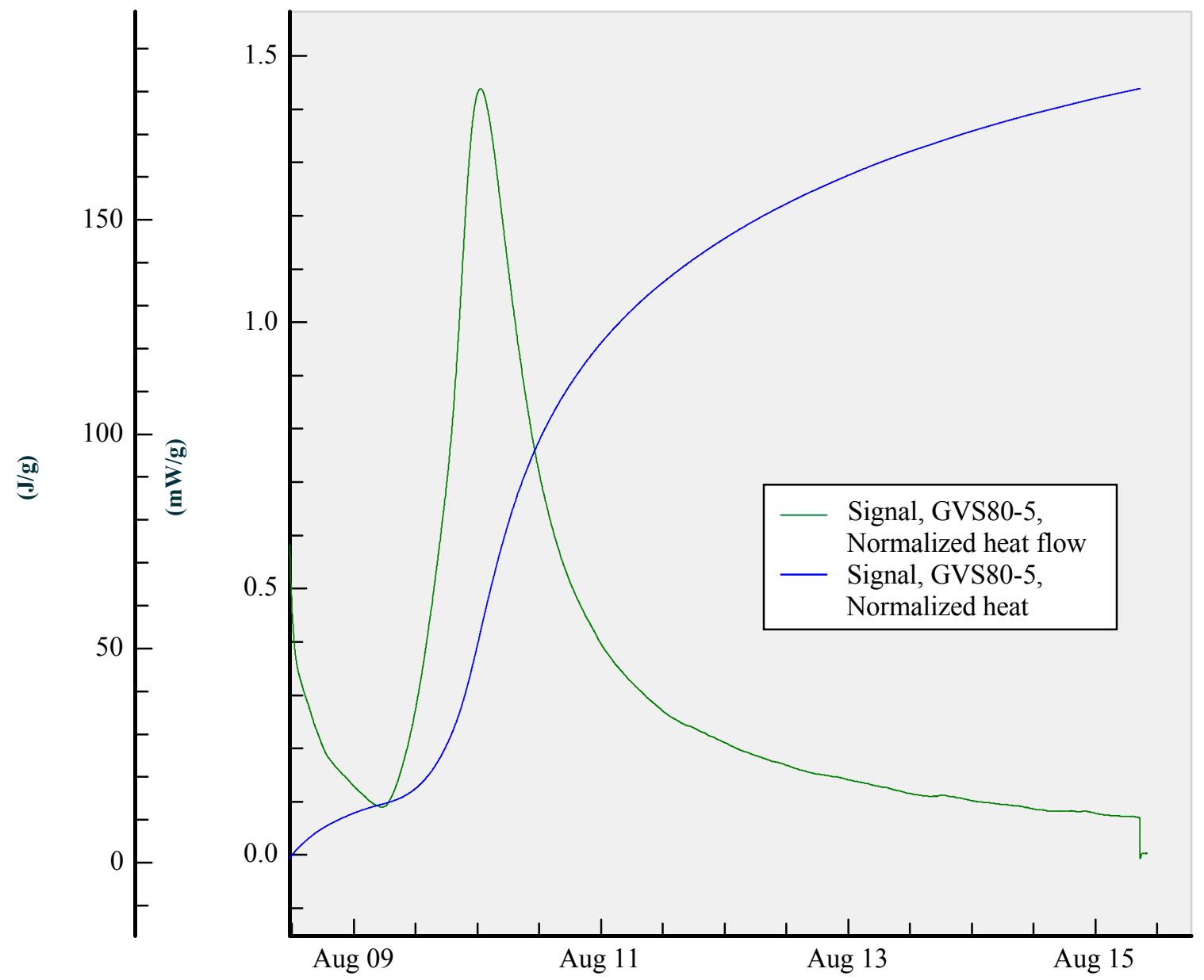

Figure 3-5 Normalized heat flow and normalized heat for GVS80

The 28-day compressive strengths for the three mixes are given in Table 3-7. These data demonstrate that the compressive strength increased significantly as the aluminate concentration was increased in the mixes.

Table 3-7 Compressive Strengths as a Function of Aluminate Concentration for the Tank 11 Mixes

\begin{tabular}{|c|c|c|}
\hline Identifier & $\begin{array}{c}\text { Cure Time } \\
\text { (Days) }\end{array}$ & $\begin{array}{c}\text { Compressive Strength } \\
\text { (psi) }\end{array}$ \\
\hline GVS 78 & 28 & 569 \\
\hline GVS 79 & 28 & 1056 \\
\hline GVS 80 & 28 & 1496 \\
\hline
\end{tabular}




\subsection{The Role of the Cementitious Material on the Aluminum Effect}

Mixes were made using the nominal SWPF simulant and the SWPF simulant with $0.34 \mathrm{M}$ aluminate with OPC, GGBFS or FA only. The results for the fresh grout properties are provided in Table 3-8. The OPC mixes gelled quickly, had no bleed water, and exhibited relatively high yield stress and plastic viscosity. For GGBFS mixes, the gel time, yield stress and plastic viscosity all decreased with increasing aluminate concentration. The FA only mixes gelled in less than 1 day, had very large bleed volumes, and low yield stress and plastic viscosity.

Table 3-8 Fresh Grout Properties of SWPF Mixes as a Function of Aluminate Concentration $(0.11$ or $0.34 \mathrm{M})$ with either OPC, GGBFS or FA as Cementitious Material

\begin{tabular}{|c|c|c|c|c|c|c|c|c|c|}
\hline \multirow{2}{*}{$\begin{array}{c}\text { Cementitious } \\
\text { Material }\end{array}$} & $\begin{array}{c}\text { Aluminate } \\
\text { Molarity }\end{array}$ & Identifier & \multirow{2}{*}{$\begin{array}{c}\text { Gel Time } \\
\text { (minutes) }\end{array}$} & \multicolumn{1}{|c|}{ Bleed (vol\%) } & Density (g/ml) & \multicolumn{2}{|c|}{ Bingham Plastic } \\
\hline \multirow{2}{*}{ OPC } & 0.11 & TR324 & 5 & 0.0 & 0.0 & 1.89 & 1.914 & 12.6 & 181.7 \\
\cline { 2 - 10 } & 0.34 & TR322 & 5 & 0.0 & 0.0 & 1.87 & 1.916 & 11.5 & 138.5 \\
\hline \multirow{2}{*}{ GGBFS } & 0.11 & TR325 & 20 & 0.0 & 0.0 & 1.79 & 1.822 & 9.1 & 99.2 \\
\cline { 2 - 10 } & 0.34 & TR323 & 10 & 0.4 & 0.0 & 1.80 & 1.883 & 5.9 & 86.5 \\
\hline \multirow{2}{*}{ FA } & 0.11 & TR326 & $>600$ & Turbid & 20.0 & 1.683 & NM & 0.2 & 56.8 \\
\cline { 2 - 9 } & 0.34 & TR327 & $>600$ & Turbid & 16.5 & 1.687 & NM & 0.3 & 51.0 \\
\hline
\end{tabular}

The set time and the 7-day heat of hydration data for these mixes are presented in Table 3-9. For the OPC mixes, the induction period (peak time) actually decreased from 2 to 0.4 hours with an increase in aluminate concentration and the set time was 1 day for both mixes. On the other hand, the properties of GGBFS mixes were similar to the properties of SWPF mixes prepared with premix and higher aluminate concentrations. The peak time increased from 6 to 32 hours and the set time increased to 2 days from 1 day. Finally, over the 7 day period, the FA mixes did not produce much heat relative to OPC and GGBFS mixes.

Table 3-9 Set Time, 7-Day Heat of Hydration and Peak Times for Heat Flow for the SWPF Mixes as a Function of Aluminate Concentration $(0.11$ or $0.34 \mathrm{M})$ with OPC, GGBFS or FA

\begin{tabular}{|c|c|c|c|c|c|c|c|}
\hline Cementitious & Aluminate & Identifier & $\begin{array}{c}\text { Set } \\
\text { Time }\end{array}$ & \multicolumn{2}{c|}{$\begin{array}{c}\text { 7-Day Heat of } \\
\text { Hydration }\end{array}$} & \multicolumn{2}{c|}{ Peak Time } \\
\hline Material & Molarity & & Days & J/g premix & J/g grout & Minutes & Hours \\
\hline \multirow{2}{*}{ OPC } & 0.08 & TR324 & 1 & 223.0 & 120.9 & 120 & 2 \\
\cline { 2 - 8 } & 0.34 & TR322 & 1 & 227.0 & 118.6 & 24 & 0.4 \\
\hline \multirow{2}{*}{ GGBFS } & 0.08 & TR325 & 1 & 281.7 & 152.8 & 347 & 6 \\
\cline { 2 - 8 } & 0.34 & TR323 & 2 & 286.0 & 149.5 & 1905 & 32 \\
\hline \multirow{2}{*}{ FA } & 0.08 & TR326 & $>7$ & 16.3 & 8.5 & None & None \\
\cline { 2 - 8 } & 0.34 & TR327 & $>7$ & 13.8 & 7.5 & None & None \\
\hline
\end{tabular}


The 14 day and extended heats of hydration for these mixes are shown in Table 3-10. It is interesting that the GGBFS generates more heat than the OPC in both simulants. A greater amount of heat was evolved with aluminate present in both cases. The heat of hydration curve for a mix prepared using FA only is provided in Figure 3-6. There is an induction period of 7 days followed by an increased rate of heat generation for 15 days before the rate is decreased again as the output levels off. In all cases, a higher aluminate concentration in the simulants increased the heat of hydration.

Table 3-10 Time Dependence of the Heat of Hydration for the SWPF Mixes as a Function of Aluminate Concentration $(0.11$ or $0.34 \mathrm{M})$ with OPC, GGBFS or FA (NM is not measured)

\begin{tabular}{|c|c|c|c|c|c|}
\hline Cementitious & Aluminate & \multirow{2}{*}{ Identifier } & \multicolumn{3}{|c|}{ Heat of Hydration (J/g premix) } \\
\cline { 4 - 6 } Material & Molarity & & 7-day & 14-day & Extended \\
\hline \multirow{2}{*}{ OPC } & 0.11 & TR324 & 223 & NM & 265 \\
\cline { 2 - 6 } & 0.34 & TR322 & 227 & 265 & 315 \\
\hline \multirow{2}{*}{ GGBFS } & 0.11 & TR325 & 282 & NM & 328 \\
\cline { 2 - 6 } & 0.34 & TR323 & 286 & 330 & 382 \\
\hline \multirow{2}{*}{ FA } & 0.11 & TR326 & 16 & 41 & 85 \\
\cline { 2 - 6 } & 0.34 & TR327 & 14 & 38 & 100 \\
\hline
\end{tabular}




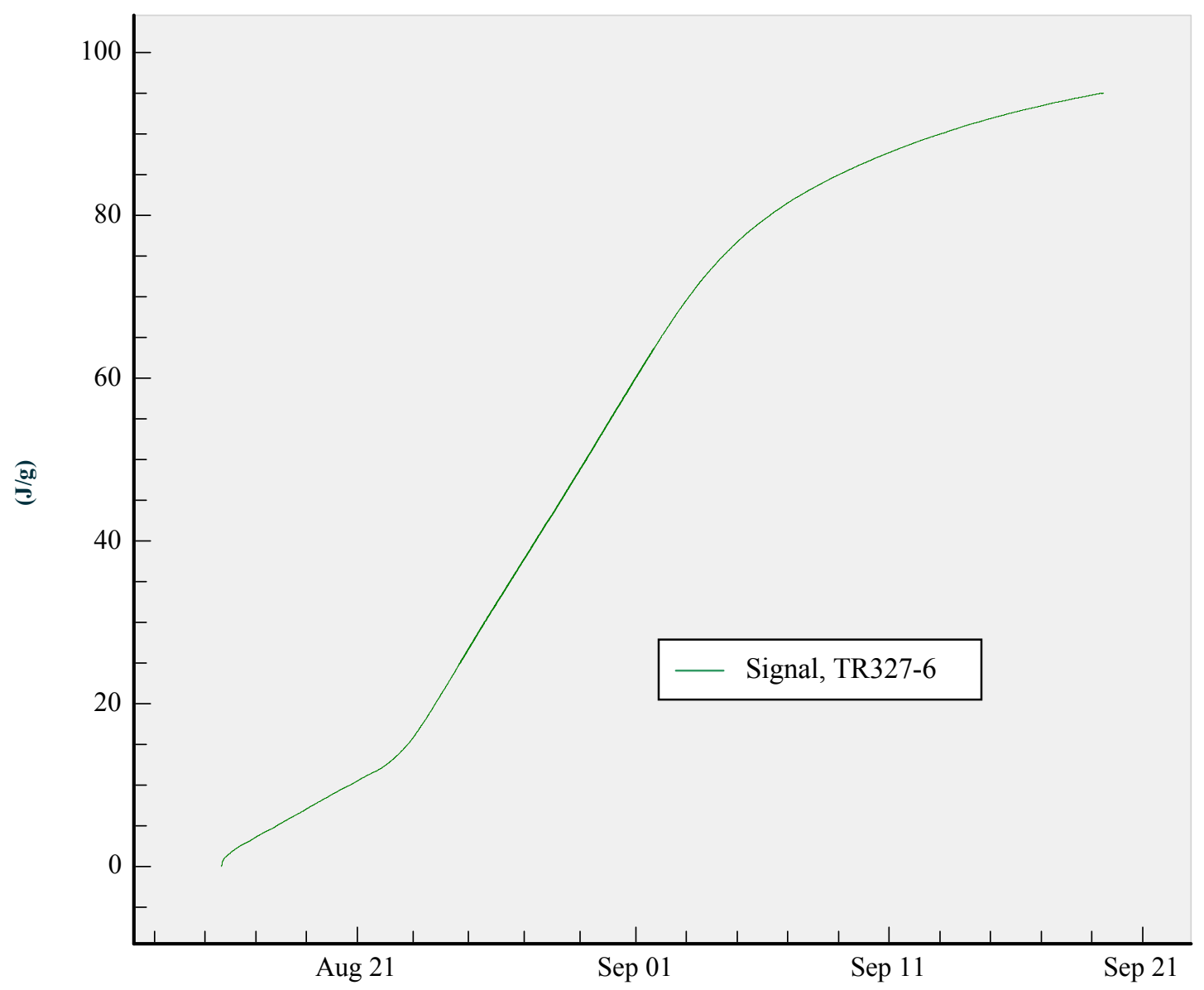

Figure 3-6 Heat of hydration response ( $\mathrm{J} / \mathrm{g}$ of FA) for a mix made from FA and SWPF simulant with $0.34 \mathrm{M}$ aluminate

It is interesting to compare the projected results for the total heat evolved obtained from summing the contributions of each of the cementitious materials independently in the mix (from Table 3-10) with the measured response from the combination of these materials (premix) as presented in Table 3-2. (Because the ratio in the premix is 10:45:45, the summation is equal to 0.1 *heat evolved for OPC $+0.45^{*}$ heat evolved for GGBFS $+0.45 *$ heat evolved for FA). The results are provided in Table 3-11. The 7 day results show good agreement. For extended values obtained by curve fitting, the actual measurements are significantly less than the sum of the three individual measurements. This most likely is due to the complexity of a ternary system of cementitious materials and indicates that interactions occur between the hydration reactions of these three components. 
Table 3-11 Heats of Hydration Values for GVS74 and GVS76 Mixes and Calculated (Summation) Values from Individual Contributions from Table 3-10

\begin{tabular}{|c|c|c|c|c|}
\hline $\begin{array}{c}\text { Cementitious } \\
\text { Material }\end{array}$ & $\begin{array}{c}\text { Aluminate } \\
\text { Molarity }\end{array}$ & \multirow{2}{*}{ Identifier } & \multicolumn{2}{|c|}{ Heat (J/g of premix) } \\
\cline { 4 - 5 } & & 7-day & Extended \\
\hline Premix & 0.11 & GVS74 & 141 & 150 \\
\hline Summation & 0.11 & GVS74 & 156 & 212 \\
\hline Premix & 0.33 & GVS76 & 162 & 200 \\
\hline Summation & 0.33 & GVS76 & 158 & 248 \\
\hline
\end{tabular}

\subsection{Porosity Measurements}

Porosity was measured for these samples as described in a previous report [8]. The total porosity values are relatively constant for the GVS mixes and agree well with previous measurements for SWPF mixes, see Table 3-12. The degree of hydration values (in units of $\mathrm{w} / \mathrm{cm}$ ) indicate relatively low amount of hydration.

The higher degree of hydration values for the TR samples are due to the fact that these samples contained only OPC or GGBFS which have previously been shown to react more completely in these systems. The porosities and degree of hydration values for these four TR samples improved with time as seen by the decrease in porosity and increase in w/cm ratio for measurements at longer cure times.

Table 3-12 Porosity Measurements for Samples at Various Curing Times

\begin{tabular}{|c|c|c|c|c|}
\hline Identifier & $\begin{array}{c}\text { Cementitious } \\
\text { Material }\end{array}$ & $\begin{array}{c}\text { Cure Time } \\
\text { (Days) }\end{array}$ & $\begin{array}{c}\text { Porosity } \\
\text { (Percent) }\end{array}$ & $\begin{array}{c}\text { Degree of } \\
\text { Hydration } \\
\text { (w/cm) }\end{array}$ \\
\hline GVS74 & Premix & 16 & 59.3 & 0.059 \\
\hline GVS75 & Premix & 19 & 60.2 & 0.053 \\
\hline GVS76 & Premix & 19 & 59.0 & 0.066 \\
\hline GVS77 & Premix & 16 & 60.6 & 0.053 \\
\hline \hline GVS 78 & Premix & 12 & 59.9 & 0.030 \\
\hline GVS 79 & Premix & 12 & 61.1 & 0.032 \\
\hline GVS 80 & Premix & 12 & 60.7 & 0.038 \\
\hline \hline TR322 & OPC & 12 & 59.3 & 0.093 \\
\hline TR322 & OPC & 42 & 55.2 & 0.128 \\
\hline TR323 & GGBFS & 12 & 58.9 & 0.088 \\
\hline TR323 & GGBFS & 42 & 54.6 & 0.124 \\
\hline TR324 & OPC & 7 & 60.0 & 0.087 \\
\hline TR324 & OPC & 35 & 55.5 & 0.125 \\
\hline TR325 & GGBFS & 7 & 54.8 & 0.108 \\
\hline TR325 & GGBFS & 35 & 52.2 & 0.131 \\
\hline
\end{tabular}




\subsection{CONCLUSIONS}

This report summarizes the initial measurements of grout properties on two waste streams as a function of aluminate concentration. The goal was to determine the impact of increased aluminate concentration in salt waste streams on grout properties as a result of the potential use of caustic sludge washing to remove aluminum.

- The set times increased dramatically as aluminate concentration increased. For the SWPF mixes, the set time increased from 1 to 4 days. The inhibition of set time by aluminate was also observed for Tank 11 mixes.

- Heat of hydration measurements were consistent with the increased set times in that the induction periods were extended to several days as aluminate concentration increased in the salt solution.

- The overall heat generation was greater in the mixes containing higher concentrations of aluminate. In fact, for the values for the total heat release at longer periods (using curve fitting), the amount of heat was increased $33 \%$ for SWPF based solutions and $46 \%$ for Tank 11 based solutions.

- The increased induction periods observed with increasing aluminate concentrations must be addressed for Saltstone operations and included in the modeling for pour schedule.

- The higher values $(\mathrm{J} / \mathrm{g})$ of heat from mixes containing more aluminate must be accounted for in the modeling effort which determines the pour schedule for Saltstone.

- It appears that the increase in total heat evolution for a mix is also dependent on the free hydroxide ion concentration. In particular, alkali activation of slag does increase with increasing hydroxide ion concentration. Aluminum dissolution may also increase the free hydroxide ion concentration due to the use of sodium hydroxide to dissolve the aluminum.

- The delay in heat evolution evidently is associated with hydration reactions of the GGBFS. OPC alone speeds up the rate of heat generation whereas GGBFS based mixes show the increase in induction period that was observed with mixes prepared using premix cementitious materials.

- FA does not react significantly during the first seven days of curing but then undergoes an accelerated burst for 15 days before beginning to level off. The total amount of heat generated from a FA only mix with SWPF salt solution at $0.00 \mathrm{M}$ aluminate is approximately $85 \mathrm{~J} / \mathrm{g}$ vs. $101 \mathrm{~J} / \mathrm{g}$ for a SWPF simulant with $0.34 \mathrm{M}$ aluminate.

- The heat of hydration measurements revealed that the ternary system of cementitious materials (premix) leads to interactions between the hydration reactions of these three components. This reduces the overall heat generation compared to what is predicted from summing the heats from three separate mixes made using only OPC, GGBFS or FA.

- The fresh grout properties of mixes made with SWPF and Tank 11 simulants were not significantly impacted by increasing concentrations of aluminate in the salt solution. In particular, the overall trend was decreased yield stress and plastic viscosity, greater flow of the grout, and reduced gel times and bleed volume (for SWPF based mixes) as the aluminate concentration in the salt feeds increased. 


\subsection{PATH FORWARD}

It is important for SRNL to receive projections of the compositions (and their ranges) of the salt solutions (including blending) with higher aluminate and free hydroxide concentrations that result from caustic treatment of the HLW sludge. Using the variability study as a basis, a welldefined, statistically-derived, experimental approach is then required to evaluate the dependence of grout properties on expected compositional and operational variables within these new compositional regions of higher aluminate and free hydroxide. As part of this approach, the heat of hydration will be measured at higher temperatures to determine the dependence of induction period on the temperature of the mix.

\subsection{REFERENCES}

[1] Scoping Studies for Development of Saltstone Variability Study, J. R. Harbour and T. B. Edwards, WSRC-RP-2005-01439, Rev. 0, 2005.

[2] Variability Study for Saltstone, J. R. Harbour, T. B. Edwards, E. K. Hansen and V. J. Williams, WSRC-TR-2005-00447, October 2005.

[3] Flowsheet for Aluminum Removal from Sludge Batch 5, J. A. Pike and J. M. Gillam, LWO-PIT-2007-00042, Rev. 0, 2007.

[4] Saltstone Variability Study - Measurement of Porosity, J. R. Harbour, V. J. Williams, T. B. Edwards, R. E. Eibling, and R. F. Schumacher, WSRC-STI-2007-00352, Rev. 0, 2007.

[5] Heat of Hydration of Saltstone Mixes - Measurement by Isothermal Calorimetry, J. R. Harbour, V. J. Williams and T. B. Edwards, WSRC-STI-2007-00263, Rev. 0, 2007. 